\begin{tabular}{ll}
$\begin{array}{l}\text { Social Work/Maatskaplike Werk Vol } 57 \text { No } 1 \text {; Issue } 3 \\
\text { http://socialwork.journals.ac.za/pub }\end{array}$ & doi:http://dx.doi.org/10.15270/52-2-905 \\
\hline
\end{tabular}

JUDICIAL OFFICERS' EXPERIENCES OF INCLUDING VICTIM IMPACT REPORTS IN THE CRIMINAL JUSTICE PROCESS

Adelette Phillips, Zurina Abdulla

Judicial officers do not consistently include victim impact reports (VIRS) because of internal and external factors experienced in securing such victim impact reports. This results in the inconsistent inclusion of VIRS during the criminal justice process, which in turn hinders the promotion of victim rights. A qualitative study explored judicial officers' experiences of including VIRS during the criminal justice process. Findings alluded to the lack of legislation, a gap in the literature and a need for specialised victim services. A need for guidelines was identified to expand on the victim empowerment programme for social workers, enabling them to work within the criminal justice system and to include VIRS during the criminal justice process.

Keywords: : criminal justice system, judicial officers, social workers, specialised victim services, victim empowerment, victim impact reports (VIRS) 


\title{
JUDICIAL OFFICERS' EXPERIENCES OF INCLUDING VICTIM IMPACT REPORTS IN THE CRIMINAL JUSTICE PROCESS
}

\author{
Adelette Phillips, Zurina Abdulla \\ Ms Adelette Phillips, Master's student, Department of Social Development Professions, Nelson Mandela University, Port \\ Elizabeth, South Africa; Social Work Manager, Department of Social Development: Restorative Services, Eastern Cape, South \\ Africa. \\ Dr Zurina Abdulla, Department of Social Development Professions, Nelson Mandela University, Port Elizabeth, South Africa.
}

Keywords: criminal justice system, judicial officers, social workers, specialised victim services, victim empowerment, victim impact reports (VIRS)

\section{INTRODUCTION}

The victim empowerment programme (VEP) seeks to improve victim cooperation in the criminal justice system, which will benefit the investigation and prosecution, while addressing issues of trauma and victimisation (Nel \& Van Wyk, 2013:79). The inclusion of victim impact reports (VIRS) is one of the tools used to enable this process. VIRS are professional assessment reports compiled by social workers within the field of victim services. Victim involvement in the criminal justice system contributes to their processing of trauma (Dinisman, Moroz, Farley, Naylor, Panagiotou, Fuller, Owen \& Almeida (2017:30). Their involvement helps to ensure justice and an effectively functioning criminal justice system (Fisher \& Simpson, 2014:1). In an adversarial criminal justice system, victims have limited to no possibility of expressing themselves or relating the impact of crime on them (Doak, 2015:148), and the criminal justice system is not designed or equipped to deal with victim trauma (Eakramuddin, 2014:55). Victim impact statements and reports have been submitted in Northern Ireland since 1980; in England and Wales they were introduced only in 2001, and in Scotland they were rolled out in 2009 (Moffett, 2016:2). In South Africa the case of the State v Isaacs is relevant as the court determined that in a criminal case certain factors that related to victims needed to be considered in sentencing (De Klerk, 2012:9 - 10). These factors included the nature of the offence, the interests of society and the interests of the victim which were demonstrated through the disclosure of the event and the impact this has had on both the victim and society (De Klerk, 2012:9 - 10). This is especially important in dealing with victims in a country characterised by racism, marginalised communities, lack of education and development, violence and crime (Saferspaces, 2019). But it needs to be acknowledged that expecting a victim to relate trauma symptoms and indicators to the criminal justice system can be challenging. Furthermore, expecting judicial officers to understand the impact of crime and to reflect on victim trauma is challenging, since they specialise in legal matters. To promote victim rights and to address the trauma of the victim, a different approach is required. Instead of the current approach where victim impact statements or oral victim impact evidence is submitted, it is proposed that inclusion of VIRS should be considered for obtaining impact evidence. Legislation (Prevention and Combatting of Trafficking in Persons Act 7 of 2013; Probation Services Amendment Act 35 of 2002; Criminal Procedure Act 51 of 1977) and case law (Bailey v The State (454/11)[2012]ZASCA 154; S v Mokela (1) SACR 431 (SCA); S v Isaacs 2002 (10 SACR 176(C); S v Ndou (93/12) [2012] ZASCA 148; S v Matyityi [2010] JOL 26275 (SCA)) have advocated for victim impact evidence to ensure a fair and balanced trial. Evolving victim services within VEP to adopt a more professional, specialised and interdisciplinary approach in dealing with victims in the criminal justice system are required to honour the rights of the victim. De Klerk (2012) observed that victim impact assessments are mainly used in sexual offence cases and this is in line with current practice observation. The aim of this study was to understand the experiences of judicial officers with the inclusion of victim impact reports during the processes of the criminal justice system through looking at factors that would promote the inclusion of these reports for all cases of serious offences as well as at factors influencing them to not include such reports. This article will provide the background to the study, the theoretical framework, the research methodology, the findings, recommendations, and the conclusions based on the findings. 


\section{BACKGROUND}

A move towards a victim-centred approach provides space for the victims' voices and their participation while promoting their empowerment (Victim Support Europe, 2013:15). This requires different intervention strategies within an adversarial criminal justice system. The Rome Statute (Rome Statute of the International Criminal Court, 1998) provided for victim participation in Article 68(3) during any appropriate stage of the criminal justice process (Fulton, 2015:9). Providing victim impact evidence during the criminal justice process created an opportunity for victim participation. Victim impact evidence is submitted to court at the sentencing stage and this evidence is submitted through various methods (Fulton, 2015:69). Internationally, victim impact statements are the most common method applied. During the criminal justice process the offender is given the opportunity to provide evidence for mitigating factors, and a fair trial would give the victim the opportunity to express, directly or indirectly, the impact the crime had on them. Case law is fundamental in South Africa for creating guidelines for cases. In the case of Bailey v the State a VIR was used for evidence of aggravating factors (Judge Bosielo, Judgement, The Supreme Court of Appeal South Africa, 2012:15) and, as such, it represents the victim's right to offer information. The VIR promotes a fair trial and as such balances victim and offender rights and participation. The ability to ensure this balance lies with judicial officials, as they have the responsibility to ensure a fair trial. VIRS are an alternative to the victim impact statement and require a forensic approach. Forensic victimology is best described as a detached, objective and scientific investigation, where critical analysis of the facts is undertaken with corroborating evidence to explain the behaviour of the victim (Turvey \& Petherick, 2008 as cited in Burgess \& Roberts, 2010:21). A VIR is victim specific with the focus purely on the impact of the crime on the victim. The main purpose of the forensic victimologist is to serve the criminal justice system and this individual obtain, examines, interprets and explain evidence (Turvey \& Crowder, 2017:8-9). In South Africa VIRS are requested by the National Prosecuting Authority (NPA) (O'Connell, 2012:8) and are undertaken by professionals such as social workers. Judicial officers have a mandate to request a professional assessment of the impact of crime on the victim and to then lead expert testimony after the submission of a report.

The Prevention and Combating of Trafficking Act 7 of 2013 mandates the compilation of VIRS (Prevention and Combating of Trafficked Persons Act 7 of 2013). Section 14(f) and (g) states that factors such as whether abuse of the victim had taken place and whether the crime has had physical and psychological effects on the victim should be taken into consideration as aggravating factors in sentencing. The age of the victim, the relationship between the victim and the accused, the victim's mental health, as well as any physical disability should be taken into account during sentencing; this information must be included in a VIR (Prevention and Combatting of Trafficking in Persons Act 7 of 2013:20-22). This Act requires that the statutory obligation of victim services be acknowledged. Trying to understand why these reports are mainly requested in sexual offence cases and not for all serious crimes motivated this research study.

Victims are left with life-changing effects from the impact of the crime (Herman, 2015:24; Rahman, 2013:3). The individualised nature of each person's trauma is not dependent on the type of crime but rather on their own individual experience. The factors that influence this are aspects such as "age, gender, ethnicity, culture, socio-economic status and social networks" (Gale \& Coupe, 2005 as cited in Wedlock $\&$ Tapley, 2016:8). Understanding and interpreting the impact is complex and requires a trauma-informed response within a multi-agency approach (Ellison \& Munro, 2016:67). The reason for this is that victims could appear as if they are not experiencing any negative impact, while they might be dissociated or disconnected from the trauma (Ronaldson \& Mccoy, 2016:4). In practice it has been observed that victims often struggle to relate the impact of crime. The study reflected on some of the challenges experienced by judicial officers to obtain evidence of impact and to include VIRS during criminal cases. Statistical information from an NGO and government in the Nelson Mandela Metro rendering victim services with reference to VIRS indicates selective requests and the reports are used mainly in sexual offence cases (Ceasor, 2017; Landman, 2017). This implies that cases with victims of hijacking, armed robbery, robbery, murder, gender-based violence and gang-related offences are excluded from accessing VIRS. 
When VIRS are used selectively it means that victim impact evidence is interpreted as a generalised conclusion about the impact, or it is assumed that there is no impact of the crime on the victim. Van der Merwe (2013:1030) noted that section 274 of the Criminal Procedures Act 51 of 1977 made provision for the submission of VIRS, but this remained optional and that practical challenges could be influencing prosecution's decision to use these reports or not.

This study explored judicial officers' understanding of VIRS and their experiences with including VIRS as well as their decision to request these reports selectively. The literature review indicated a gap in the literature on victim impact reports and a lack of guidelines on VIRS. Therefore, this qualitative study was conducted to explore judicial officers' experiences of including VIRS during the criminal justice process. It is envisioned that this research will lead to a higher awareness of the need to include VIRS to promote the rights of the victim and to promote an understanding of the statutory obligation of the Department of Social Development for VIRS.

\section{Theoretical framework}

An interpretive approach was followed to analyse data in line with the general theory of victimology in criminal science and the critical social theory. The general theory of victimology in criminal science (Rayejian Asli, 2014) addresses two main streams of victimology, namely criminological victimology and assistanceorientated victimology. Rayejian Asli (2014) addresses victimology through victim participation, reflecting on the variety of harms that may have an impact on the victim. His second concept refers to victim passivity; this entails a paradigm shift from an offender-focused approach to a victim-assistance approach while addressing victim rights. Original victimology theories developed within a criminological approach (Saponaro, 2009, as cited in Saponaro, 2013:21). It shifted responsibility to the victim for the crime committed and provided for mitigating factors for the offender. An assistance-orientated theory shifts the blame away from the victim and rather focuses on the impaired rights of the victim and the harm impacting on the victim. It reflects on the phase or state that individuals are in for them to be classified as victims (Rayejian Asli, 2014:63). The concept reflects on the impact of the crime on the individual in terms of physical harm, mental and emotional impact, as well as financial loss and impairment of rights. According to Rayejian Asli (2014), each of these harms or impacts requires intervention for the victim. Rayejian Asli (2014) developed a sixlevel model of intervention as illustrated in Figure 1.

\section{FIGURE 1}

SIX-LEVEL INTERVENTION MODEL

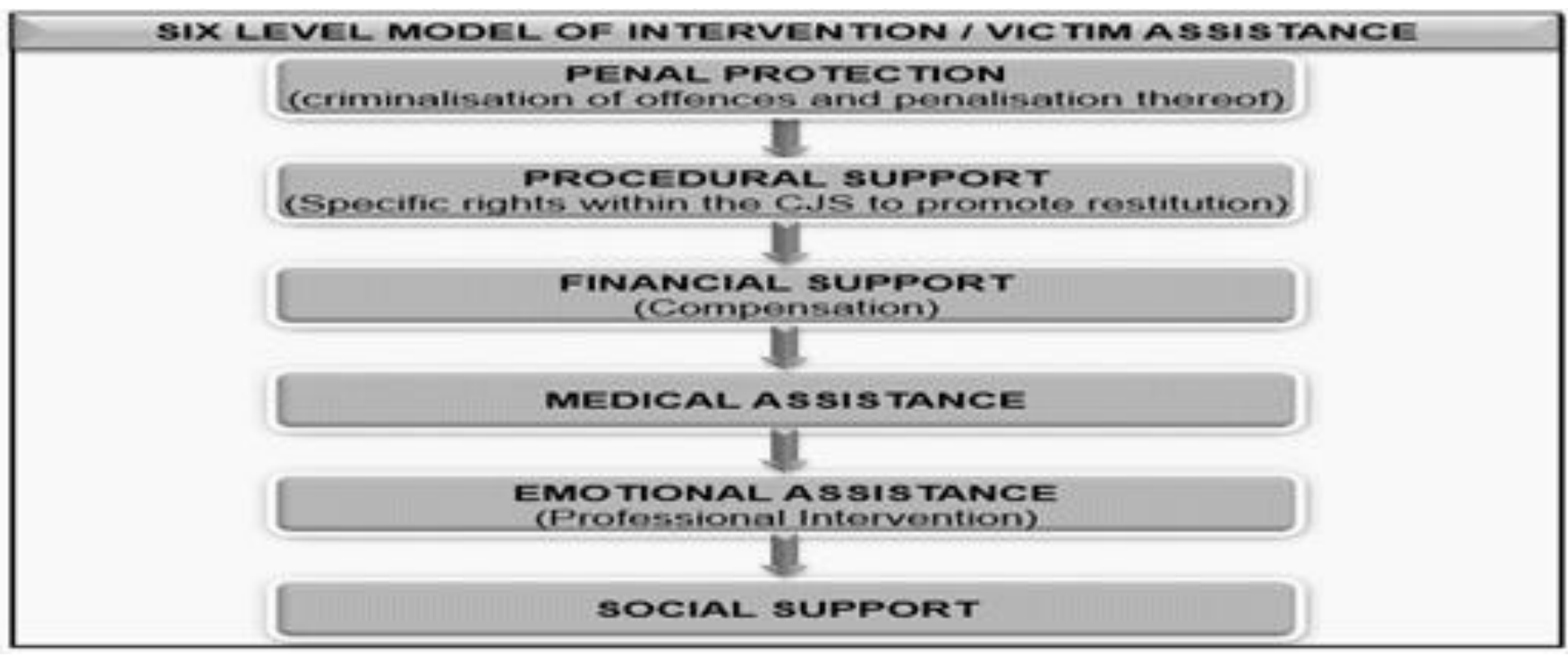

Provision has been made for the offender's rights to be considered in a fair trial and, since the development of victimology, provision is made for victim rights to be addressed and promoted as well (Rayejian Asli, 2014:68). 


\section{RESEARCH METHODOLOGY}

A qualitative approach employing an explorative, descriptive and contextual design was followed. The study explored the nature of the use of impact evidence through VIRS and how this was perceived, interpreted and implemented by judicial officers during the criminal justice process. The objectives of the research included exploring and describing the judicial officers' experiences of working with VIRS as well as exploring the factors that contribute towards including VIRS in the criminal justice system. Trustworthiness was achieved through the exploration of the personal experiences of the judicial officers and the findings therefore reflect their subjective interpretations of including VIRS during the criminal justice process. The accurate reflection of the participants' views enhanced the credibility of the study as the participants will be able to confirm their own individual contributions made to the study. Transferability was enhanced as all participants' practise within the criminal justice system in various courts and are linked to either prosecution or presiding officers. Dependability was promoted through a logical and traceable process in which the methodology can be duplicated but the experiences reflects subjective uniqueness Credibility was enhanced through an independent coder as well as supervisor verification and verbatim reflection of interviews conducted. Ethical clearance received from Nelson Mandela University, with reference number H17-HEA-SDP-012, is applicable to this study. Ethical considerations included ascertaining the willingness of the participants to participate, evaluating the benefits of the study in contributing to the body of knowledge and for the research to assist the participants in creating an awareness of social work responsibility in the criminal justice system.

A non-probability purposive sampling technique was used to identify judicial officers, particularly magistrates and prosecutors, who are currently employed in the criminal justice system within the Nelson Mandela Metro. All participants who indicated their willingness to participate voluntarily in the study were included in the research if they were employed within the criminal justice system and were either a prosecutor or a presiding officer linked to a court within the Nelson Mandela Metro. One participant who indicated a willingness to be included was a judge and therefore a presiding officer, but had to be excluded because the geographical area was not covered by the ethical clearance.

FIGURE 2

RESEARCH PARTICIPANTS

\begin{tabular}{|l|c|}
\hline Total participants volunteering & 18 \\
\hline Total number of participants interviewed & 16 \\
\hline Number of participants not qualifying for inclusion & 1 \\
\hline Number of participants not adhering to appointments & 1 \\
\hline Total number of prosecutors participating & 11 \\
\hline Total number of magistrates participating & 5 \\
\hline
\end{tabular}

An independent interviewer conducted the individual semi-structured interviews with 16 participants. The independent interviewer is a retired social work manager with many years of experience and competent in conducting face-to-face interviews. Interviews were audio-recorded by the interviewer once participants' consent had been obtained. The audio-recording enabled accurate capturing of information and this allowed the interviewer to focus on observing the non-verbal communication and underlying feelings projected during the interview (Greeff, 2013:359). The demographic information of the participants is indicated in Table 1. 
TABLE 1

DEMOGRAPHIC INFORMATION

\begin{tabular}{|l|l|l|l|}
\hline Gender & \multicolumn{4}{l|}{} \\
\hline Male & 6 & Female & 10 \\
\hline Area of operation & 13 & Uitenhage & 3 \\
\hline Port Elizabeth & \multicolumn{3}{|l|}{} \\
\hline Court Level & 3 & Children's Court & 1 \\
\hline District Court & High Court & 4 \\
\hline Regional Court & \multicolumn{3}{|l|}{} \\
\hline Occupation & Magistrate & 5 \\
\hline Prosecutor & 11 & Xhosa & \\
\hline Language & Afrikaans & 2 & \\
\hline English & 7 & & \\
\hline 7 & & & \\
\hline
\end{tabular}

Interviews were transcribed by an independent transcriber. Once all transcripts had been received, coding and data analysis were done as a step-by-step method following the five steps listed by Watling and James (2012, as cited in Vosloo, 2014:360-361). This method required the identification and classification of data in relation to the research question. The data were then sifted to determine relevance and applicability. The data were sorted and coded through being divided into segments to identify relevant themes. This enabled the development of subthemes and categories. Data analysis was conducted through thematic data analysis. Coding and data analysis were confirmed through an independent coder. Participants were allocated a number reference to secure confidentiality. Participants $1,2,6,10$ and 12 were magistrates, while the other participants were prosecutors.

\section{FINDINGS}

The data generated five themes: Theme 1: Judicial officers' understanding of VIRS; Theme 2: Judicial officers' experiences of including VIRS during the criminal justice process; Theme 3: Factors that promote judicial officers' utilisation of VIRS during the criminal justice process; Theme 4: Factors that contribute to judicial officers' excluding VIRS in the criminal justice process; and Theme 5: Recommendations for the utilisation of VIRS during the criminal justice process. Given the scope of this article only themes 1,2 and 4 will be dealt with here as they reflect on the judicial officers' understanding and experiences of VIRS during the criminal justice process.

\section{Theme 1: Judicial officers' understanding of VIRS}

Two sub-themes emerged within the Theme: Judicial officers' understanding of VIRS and will be discussed in the following sections.

\section{Sub-theme 1.1: VIR understood as a professional assessment of the impact of the crime on the victim}

The participants understood VIRS as a professional assessment of the impact of crime where a comparison is made of the individual's changed behaviour before and after the crime was committed and the trauma indicators. This assessment should not only be based on the victim's oral testimony, but should also include a professional observation and assessment of the presenting facts (Joubert \& Van Wyk, 2014:498). Forensic social work is about collecting facts based on the evidence obtained through interviewing and observation (Mangezi, 2014:11). The participants indicated that these reports mainly focus on the primary victim and they require a detailed account that addresses the psychological wellbeing (inclusive of trauma triggers), the emotional and physical impact on the victim as well as the cost incurred as a result of the crime. One excerpt demonstrating participants' understanding of VIRS can be reflected as follows: 
The emotional status, psychologically, how she, it affected that person and emotionally, the trauma that she's now experiencing, or she has experience in future. I, I mean it's where you'll be able to see in the long run, future, whether this person will be able to cope. What intervention will be needed to deal with the trauma that she's now undergoing or with the psychological effects or their inside, all those behaviours. (Participant 10)

The findings indicated that eleven judicial officers were aware of VIRS. Eight judicial officers had sufficient knowledge regarding the content of the reports and had been exposed to VIRS. It could be concluded that the participants who had been exposed to VIRS understood these reports to be in line with the forensic victimology description of VIRS and that the reports were seen as an "accurate, critical and objective" description of the circumstances of the victim (Ferguson \& Turvey, 2009:21), while reflecting on the event or crime-related incident and the harm suffered by the victim as a result of the incident. From the limited literature available no specific account could be obtained on judicial officers' understanding of VIRS. Their reflection on these reports therefore had to be measured in relation to the definitions and concepts provided in the literature on VIRS.

Judicial officers from the high court and specialised units understood that it had been mainly social workers responsible for victim services within VEP who have compiled these reports and who have submitted these reports to court:

They're excellent in what they are doing (referring to the victim services social workers at the One Stop Centre). They, they're one of my preferred places to go to, but I also try and manage which cases is going there so only my most severe cases is currently going there. Because I don't want to over-utilise them, and then we have nobody. (Participant 16)

Social workers are in the best position to come and do that then. Social workers are definitely needed in this criminal justice system. (Participant 15)

Most of the participants (fourteen) noted that social workers are responsible for the impact assessment, court preparation, needs assessment, emotional support during the trial and eventually the delivery of expert witnessing. This finding is consistent with Mangezi's (2014:38) findings that $80 \%$ of these social workers are linked to VEP. Eight judicial officers noted that social workers' involvement during the criminal justice process created access to services for the victims and enhanced victim empowerment. Services should focus on promoting the rights and the concerns of the victim within the criminal justice system; representing the victim and services should address challenges experienced during the criminal justice process to prevent secondary victimisation (Department of Social Development, 2009:29). This concurs with Moffett's findings from interviews with legal representatives which found that they saw the reports to be more reliable and accurate in terms of their analysis (Moffett, 2016:3).

One participant noted that although it is not the norm to have a victim impact report at the beginning of the trial, it assists the court to understand the emotional state of the victim and to be more sensitive to the needs of the victim. Based on practice observations within victim services, informing the court on the emotional state and possible behavioural reactions of the victim while testifying assists judicial officers when dealing with the victim as a witness. This links with the points raised by Joubert and Van Wyk (2014), who reflect on pre-prosecution and trial social work forensic reports. Pre-prosecution reports refer to the ability to testify, whether to continue with prosecution and the impact of testimony (Joubert \& Van Wyk, 2014:495-496).

The findings indicated that some judicial officers observed that victims experience challenges to relate the impact of the crime on them and therefore understood VIRS to be beneficial for the victims. The reasons identified by the participants were: challenges in accessing the victims again at the sentencing stage; refusal to provide impact information because of fear; lack of resources; inability to articulate the impact; oral impact testimony was allowed only a few minutes; and victim confidence. Research has identified three main reasons why victims did not to submit victim impact statements, namely: their psychological state (Lens et al., 2013:27), their view of re-victimisation (Byrne \& Huges, 2009:9) and 
their perception of the impact (Lens et al., 2013:492). The benefits listed by the judicial officers in using a VIR are as follows: protecting the identity of the victim; preventing secondary victimisation by avoiding reliving the trauma again; providing protection for the victim; empowering the victim to be a stronger witness; giving a voice to the victim during the criminal justice process; and providing the victim with the opportunity to access professional services for a victim's needs assessment in order to meet their needs more effectively. Krause (2014) noted the advantages of using a victim impact statement are to strengthen the court case and to lessen the burden on the victim (White, Bornman \& Johnson, 2015:17).

\section{Sub-theme 1.2: Judicial officers' misunderstanding of VIRs as victim impact statements or a probation report}

VIR terminology is still not well established within the South African context and is not well described in the literature. The terminology of the different reports remains confusing as was observed with the interchangeable use by the participants of victim impact statements, VIRS and probation reports.

... whilst if it's a victim impact statement, the complainant is at court. She writes a report here. (Referring to the victim impact statement completed by the victim). (Participant 3)

... victim impact statement reports are of a quality; a high quality and it actually meets the requirements that it should have. (Participant 7 )

Victim impact statements were clearly defined by six participants as statements written by the victim with the assistance of a court preparation officer, while other participants referred to a victim impact statement as a VIR. A victim impact statement is defined in section 70(1) of the Child Justice Act 75 of 2008. It is a sworn statement made by the victim indicating the impact of the crime on the victim's physical, psychological, social, financial situation, and the related consequences of the offence on them (Terblanche, 2013:330). VIRS are sometimes referred to as victim impact assessment reports or forensic reports. Mangezi (2014:18) observed the report to be a screening report which is seen as an assessment report to determine the effect of abuse. VIRS reflect on the physical, psychological and social impact on the victim: trauma-specific symptoms are evaluated, as well as possible long-term effects of the offence on the victim (Byrne \& Huges, 2009:9). Moffett (2016:7) noted that victim impact reports had become a controversial issue, as in many cases they were simply a repetition or recording of the victim's statement. A victim impact report is that the report must contain corroborated evidence. He stated that this might reflect badly on the expert, as well as on the lack of editing by the prosecution (Moffett, 2016:7). A VIR requires interpretation, evaluation and a theoretical explanation of the information obtained, and observation made of the symptoms displayed and victim behaviour to reach certain conclusions and make recommendations (Joubert \& Van Wyk, 2014:498).

Five participants referred to a probation report, commenting only on a paragraph and not clearly indicating the victim impact:

You get a probation officer's report and then there's like one or two lines that focus on the victim. (Participant 5)

Reference is made to a probation report that was designed to be offender specific (De Klerk, 2012:38). The probation report with the specific reference to a pre-sentence report does have a section referring to victim impact; from practice experience as well as described by one of the participants it is usually described only within a paragraph. It could be argued that this approach would not be in line with what Rayejian Asli's (2014) general theory of victimology proposes as the concept of victimhood would then be seen as part of the victimisation under the term 'harm', and would not obtain its distinctive status of victimhood. This could lead to the misrepresentation of the victim and victim rights would not be addressed. The focus of the probation report is on the accused; the aim of the report is to assist the defence in obtaining mitigating factors for sentencing and it is requested as an aid for the accused person (Van der Hoven, 2006 as cited in De Klerk, 2012:38). Impact evidence in South Africa was governed by the Probation Services Act (Probation Services Act 116 of 1991), while the development of the National 
Crime Prevention Strategy (Rauch, 1996) led to the development of a victim-centred approach from which VEP developed to address and promote services to victims.

The establishment of VEP marked a shift to a victim-focused unit and practice suggests that probation officers are not necessarily trained in impact assessments, while providing victim services is not part of their core function. Joubert and Van Wyk (2014) reflected on a lack of independent acknowledgement of victim impact reports but that instead reference is made to pre-sentence reports compiled by probation officers whose focus is on the accused and not on the victim. The aspects covered in pre-sentence reports are aspects such as the character of the accused, rehabilitative possibilities, remorse and mental state of the accused (Van der Hoven, 2006 as cited in De Klerk, 2012:38). When observing the focus of the presentence or probation report and what is being said by the participants, one could conclude that a probation report will be in direct conflict with the VIR, as it alludes to mitigating factors while a VIR would reflect on aggravating factors. The development of victim empowerment services or victimfocused social work services created challenges. These challenges included a lack of designated social workers to perform victim services, and no clear boundaries between victim social services, child protection services and probation services. These entwined services have led to in confusion in terminology and the job description of social workers. This speaks to the recommendation made for the clarification and prioritising of victim empowerment role players within the Department of Social Development (Western Cape Government: Social Development, 2014:iv).

\section{Theme 2: Judicial officers' experiences of including VIRS during the criminal justice process}

The second theme focused on judicial officers' experiences relating to the inclusion of VIRS during the criminal justice process. Two subthemes were identified: VIRS experienced by judicial officers as a multifaceted dynamic in the criminal justice process and judicial officers' experiences with the utilisation of VIRS.

\section{Sub-theme 2.1: VIRS experienced by judicial officers as a multifaceted dynamic in the criminal justice process}

Most judicial officers described positive experiences with VIRS. Nine participants experienced VIRS as making a positive contribution to the criminal justice process because of its multifaceted nature, which was seen to promote victim rights and access to services:

... to give the court a better understanding, you know, to give the magistrate or the judge a better understanding from a professional point of view as to what it is, what effect it is that this crime had on your actual complainant. (Participant 15)

If there is a VIR, then it would be so much better to motivate sentencing. Especially if he had things on appeal. You cannot motivate what you are doing if you do not have it. (Participant 12)

The multifaceted dynamics of the VIRS were attributed to the comprehensive nature of the reports; securing the availability of social workers; balancing the mitigating and aggravating factors during sentencing; promoting objectivity and balance in the criminal justice system; promoting access to information; describing the impact of the offence in terms of the short- and long-term implications of the crime (Moffett, 2016:2); equipping the court on how to deal with the victim; and sensitising the offender in terms of the consequences of their actions (Roberts, 2009:401). This concurs with Ekström and Lindström, (2016:265), who point out that social work services available to victims during the criminal justice process led to increased prosecution. According to Roberts and Manikis (2011:9), this places the court in a position of sentencing based on the facts as they are informed of the specific impact on the victim. They noted that should the court conclude sentencing based on a generic level of impact or harm, the result would be loss of proportionality as well as justice. VIRS educate judicial officers on the emotional state of the victim as well as the short-term and long-term impact of the crime on the specific victim. Wasserman and Ellis (2010:6-1) described different levels of functioning of a victim in terms of 
immediate short-term and long-term reactions after the crime had been committed (Wasserman \& Ellis, 2010). Victim Support Europe (2013) noted the criminal justice system was not designed or equipped to deal with victim trauma and this does not fall within its discipline or field of specialty. Judicial officers may not be aware of the uniqueness of the impact or harm on victims as they are not behavioural science experts and this could contribute to the haphazard implementation of the VIRS. Sensitising the criminal justice system to the complexity of trauma and the individualised impact of crime could assist in promoting the inclusion of VIRS. Dinisman, Moroz, Farley, Naylor, Panagiotou, Fuller, Owen and Almeida (2017:30) found that across all crime types, victims experienced impact on their emotional or psychological wellbeing and their sense of safety and security.

\section{Sub-theme 2.2: Judicial officers' experiences with the utilisation of VIRS}

Judicial officials' experiences with the inclusion of the VIRS can be viewed as positive, although some did indicate challenges with these reports. The positive experiences related to the content of the reports, the quality of the reports, the structure of the reports and the professionalism with which they were presented. They enable expert witnessing on victim impact within the criminal justice system. The participants reflected as follows:

I find that the majority of it has a structured format and if everything is included as it should be, then usually there is no problem then all-your theories and stuff comes into play. (Participant 6)

I always say to social workers, they say they are afraid to come and testify, I must say, and I say ... you must stand in full by your report. And, you are the expert. So, if you come and testify irrespective of what the attorney says, or the magistrate, or the prosecutor. You are the expert in this field. (Participant 3)

Aspects of importance for judicial officials include the recommendations and professional opinion of social workers based on their assessment of victims and the application of relevant theories. The inclusion of VIRS ensures that a professional person, such as a social worker, is attached to the criminal case. This means that an expert witness is available to testify on the impact of the crime on the witness, implying that the victim will not be cross-examined on the impact that is claimed to be displayed, nor will it result in an emotional outburst by the victim (as often described by professionals). The failure of the expert to give proper testimony would compromise the evidence (Burfurd, 2012:116). The judicial officers involved in this study found this was helpful within the court and assisted in preventing secondary victimisation (Phillips, 2019:170). The definition of an expert witness as described by Stern (1997:6 cited in Malatji, 2012:20) is a person who had training, knowledge and experience within the field of specialisation. This secures information and an expert opinion on the specific topic to strengthen the criminal justice system (Malatji, 2012:2). It reflects on the knowledge base and skills of the social workers and how they maintain themselves in court as reflected from the participant's input: "you must stand in full by your report. " Magistrates would be more inclined to accept reports reflecting the expertise of a professional person.

Judicial officers reflected on negative experiences with reports from social workers in general. These challenges related to time frames for assessments, linguistic and structural presentation of the reports, report completion and report writing. As such the reports could impact severely on the criminal justice process to the extent that they influence the outcome of the criminal case:

... takes up to six to eight weeks to get a report. (Participant 1)

You bring a sloppy report in and then it's not properly presented then obviously it's going to be a problem. (Participant 6)

Well for me personally, I think that is not, uhm, a sufficient VIR, because there is too much time in between the report being drafted or done and the information gathered. (Participant 16) 
No legislation or directives are currently in force on the prescribed time period for the submission of a VIR. A six-week period is prescribed for a pre-sentence report (Child Justice Act 75, 2008:50). In practice as little time as one to two weeks has been made available for the completion of victim impact assessments and VIR compilation. The timely submission of reports and the time frame from when the assessment was conducted in relation to the offence committed and when the report is completed is of the utmost importance within the criminal justice system. Taking cognisance of the importance of time, this study's findings highlight that consideration must be given to when reports are requested and whether it is in line with respecting the victim's rights to relate impact only at the sentencing stage. Doak (2015) observed three main challenges with the inclusion of victim participation within the criminal justice system. The first is that the victim rights are not legislated as they are in declaration form and there are no means to enforce these rights; second, there is still confusion even amongst legal practitioners in terms of the use of victim impact evidence and how it should be used to address mitigating as well as aggravating factors (Doak, 2015:149); this is because of ambiguous instructions. Third, the content of VIS has created a number of challenges and while it is implemented to allow a voice for the victim, it fails to do this should the victim be unable to relate the true impact. This raises the question of whether referrals or requests for a VIR should not be made earlier in the criminal justice process. A very limited time period assigned for an impact assessment creates the impression that victim needs are not addressed, especially when the investigation, the pre-trial procedures and the trial have taken a long time. It further implies that the original impact was never addressed, creating more long-term implications for the victim. The conclusion is that appropriate time frames are important for completing victim impact assessments. To balance the scales of justice, the victim should be accorded the same time and opportunities as the offender. Joubert and Van Wyk (2014) alluded to the negative experiences of judicial officers with social work forensic reports (probation reports; VIR and Section 21 rehabilitation reports). Their study identified similar challenges that were experienced by judicial officers with the quality of social work forensic reports (Joubert \& Van Wyk, 2014:494). It appears that the judicial officers in the current study, who reflected on the challenges or negative experiences did not necessarily refer to the VIR, but instead referred to probation and children's court reports as they had specifically alluded to those reports or had no experience with the VIR and therefore made a general assumption.

\section{Theme 4: Factors that contribute to judicial officers excluding VIRS in the criminal justice process}

Two sub-themes emerged within this theme. The subthemes refer to internal and external factors influencing the exclusion of VIRS.

\section{Sub-theme 4.1: Judicial officers exclude VIRs because of internal factors}

Internal factors refer to systemic factors: the lack of knowledge about VIRS, how to utilise these reports, and the personal experiences of judicial officers.

\section{Systemic factors}

Three systemic factors related to the legal prescripts, policies and procedures, role clarification and an offender-oriented criminal justice system were identified by the participants as demonstrated through the following:
The Act doesn't really say, unless they, the accused is a minor
he feels that it's a waste of time - or that [what] prosecutors want are stats driven. (Participant 3)
... are stats driven [referring to the system], so they want the case finalised as soon as possible. Magistrates, they are also under pressure to have certain stats, you know, by certain times - they must have certain finalisations. (Participant 15)

The findings demonstrated the lack of a legislative framework impacting on the implementation of victim services. The Western Cape Department of Social Development commissioned research into evaluating VEP in the Western Cape. This research mentioned the need for a comprehensive legal framework to guide victim services (Western Cape Government, 2014:144). The lack of literature, legislation, 
directives and a quantity-driven system contributes to the limitations in the utilisation of these reports. The process of having a quantity-driven system is not automatically in the best interests of the victim. Victim services require quality and the healing and empowerment of the victim is a process determined by the victims' own abilities and personal resources (National Institute of Mental Health, 2019).

\section{Knowledge base}

A lack of knowledge in terms of VIRS, services available and following good work ethics were listed as contributing factors to excluding VIRS:

... knowledge to call for whatever information is needed. Doing their work properly. (Participant 6)

The findings concur with the Implementing Victim-Oriented Reform report (Biffi, Mulder, Pemberton, Santos,Valério, Vanfraechem \& Van der Vorm, 2016:164), which noted that training was required. The need for training and workshops on role definition and relevant court procedures was also observed in South Africa (Malatji, 2012:46-47). A recent study, however, noted that the judiciary and prosecuting authority received sufficient training in dealing with sexual offences and that training needs were more relevant to other stakeholders in victim services (Heath, Artz, Odayan \& Gihwala, 2018:153).

\subsubsection{Personal experiences}

The findings indicated that some judicial officers have had negative personal experiences within the criminal justice system, which makes them more inclined to dismiss VIRS:

...magistrate would say, ag, there's no purpose in that, let's just proceed (Participant 3)

Personal perceptions and interpretations could contribute to excluding VIRS as not important or beneficial. This would prevent victims from accessing services and would impact on their perception and their own belief systems regarding the effectiveness and reliability of the criminal justice system. In this regard, Wemmers (2013:230) observed a correlation between the healing process of victims and their perception of how they are dealt with in the criminal justice system. Herman (2005, cited in Van Camp $\&$ Wemmers, 2013) noted that victims need validation and support from the criminal justice system to reduce the stress experienced.

\section{Sub-theme 4.2: Judicial officers exclude VIRs because of external factors}

This refers to the shortage of social workers within victim services, the time frame for submission of VIRS, the generic completion of these reports and unprofessional social work reports:

...uhm, whether it's because they are situated in a rural area where social workers are not readily available. (Participant 7 )

... takes up to six to eight weeks to get a report. And, that's a huge delay, uhm, beside the fact that you're dealing with so many cases. (Participant 1)

I need people to do that so, so now Social Development got a social worker there, but they cannot with their workload do all the victim impacts. ... the ideal is a proper report. So, that's the challenges experienced and then the other challenge is the fact that there's really, I get the idea sometimes that people just get this, uhm, and then they don't know how to do it and then they do it whichever way they think they should do it - and then it's, it's not a good report. (Participant 16)

The need for social workers in the criminal justice system was highlighted by White (2014), as she cited the Western Cape Forum for Intellectual Disability (2014) with specific reference being made to sexual assault cases (White, Bornman \& Johnson, 2015:28). Murphy and Barkworth (2014, cited in Wedlock \& Tapley, 2016) noted the importance of the criminal justice system working in cooperation with victim support services. Machisa, Jina, Labuschagne, Vetten, Loots, Swemmer, Meyersfeld and Jewkes (2017:114) recommend that Social Development should include more social workers in sexual offence cases (Machisa et al., 2017). They recommended the deployment of trained social workers to assist in 
the prosecution of cases. Busch-Armendaris, Nsonwa and Heffron (2014:16) indicated that the strengthbased approach in social work promoted a trusting relationship between the victim and professionals in service delivery. This promotes the three elements of prevention, prosecution, and protection of victims (Busch-Armendaris et al., 2014:16). Heath et al. (2018:163) observed the lack of availability of social workers at court for victim services. It therefore appears that we have failed in our statutory obligation to meet the dire need for victim services linked to the criminal justice system.

Judicial officers indicated that they would exclude unprofessional social work reports. Good report writing skills are required within the criminal justice system as the presiding officers are dependent on accurate information (Mangezi, 2014:58). The participants were more in favour of specialised victim services than a generic approach. Social workers dealing with victim services need to have in-depth knowledge regarding VIRS and report-writing skills. The knowledge base and efficiency of social workers rendering services within the criminal justice system have been stressed in the literature (Joubert \& Van Wyk, 2014:497). Malatji (2012:46) identified the importance of specialised training. If in South Africa it is claimed that victim services are a priority (South African Government, 2019), not only do we need dedicated social workers, but they need to be well skilled and there should be sufficient staff to deal with the demand in the criminal justice system.

Theme 4 reflected that VIRS are excluded on the basis of internal and external factors. Internal factors included systemic factors, lack of knowledge and negative personal experiences, while the external factors related to lack of available social workers in victim services, the waiting period for reports, a generic approach and unprofessional reports.

\section{CONCLUSION AND RECOMMENDATIONS}

This study reflected that victim services within the criminal justice system could bring about change towards a more victim-centred approach (Byrne \& Huges, 2009; Lens, Pemberton \& Bogaerts, 2013; Roberts, 2009). In critically reflecting on the participants' responses, it is observed that judicial officers based at the sexual offences, regional and high courts, who know about the VIRS, have been exposed to victim services and who have used the reports are more positively inclined to include the reports in the criminal justice process. Judicial officers linked to other courts did not demonstrate the same awareness, knowledge or positive inclination to include these reports. This creates a concern, specifically for serious crimes such as gender-based violence cases, as they are dealt with in magistrate's courts. The findings are therefore in line with anecdotal evidence that victim impact reports are mainly requested and used in cases involving sexual offences against minors and adults with mental disabilities (Ceasor, 2017; Landman, 2017). This raises a concern as Langton and Truman (2014) observed that more serious or violent crimes were more likely to cause higher levels of emotional stress for the victims. Violent crimes with the highest levels of stress were indicated for rape or sexual assault with $46 \%$ of victims experiencing severe distress, while $42 \%$ of victims of robbery experienced severe distress. Domestic violence indicated severe distress with a 53\% indication (Langton \& Truman, 2014:17). This links with the findings in the Implementing of the Victim-Oriented Reform of the criminal justice system in the European Union Report that internationally services were available to victims within specific categories of crime such as sexual offences, with little or no access for other victims of crime (Biffi et al., 2016;132). No proper guidelines or directives are available on referrals of victims to victim services, as this is left in the hands of the state to decide (Van der Merwe 2013:1030). Judicial officers exposed to VIRS compiled by social workers and their experiences and understanding of these reports have highlighted several aspects that need to be addressed within South Africa. VIRS are understood by judicial officers as entailing a professional assessment by a social worker on the impact of the crime, while alluding to the trauma indicators through observation and investigation. Greenbaum (2013:155) noted that VIRs were mainly completed by social workers or probation officers. The reports received from victim services are comprehensive, provide a holistic view and enable an expert witness to testify on the impact of crime. They assist the judicial officers to better understand the impact of the crime as they do not specialise in behavioural science. According to Roberts and Manikis (2011:9), the court is placed in a position of passing sentence based on the facts in front of them when they are informed of the specific

Social Work/Maatskaplike Werk 2021:57(1) 
impact on the victim in the specific case. The benefits of including these reports include a more victimfocused criminal justice system as this promotes victim rights, protects the victim, prevents secondary victimisation, links the victim to professional victim services, promotes victim empowerment and emotional support during the criminal justice process, while strengthening the victim in becoming a stronger witness. Bradford (2011:18) observed that contact with victim services increased the victim's sense of procedural fairness, thus experiencing the criminal justice system to be fair. Obtaining impact evidence is negatively influenced due to inability to access the victim, victims refusing to provide impact evidence because of fear, a lack of resources, inability to verbalise impact, and the impact evidence provided is limited.

Acquiring these reports is constrained as a result of internal and external factors. Internal factors are systemic factors, lack of knowledge and personal negative experiences. The systemic factors include legal prescripts, policies and procedures, role clarification, and an offender-oriented criminal justice system. De Klerk (2012) noted the need for legislation, and Dey, Thorpe, Tilley and Williams (2011) proposed victim empowerment legislation for clear role clarification within the criminal justice system to promote the implementation of victim rights. Mbowana, (2016) and the Western Cape Department of Social Development (Western Cape Government: Social Development, 2014:137) concluded that the legislation and policies available seemed fragmented with no specific legislation focusing only on victim services. External factors are mainly linked to the lack of available social workers for victim services; a generic approach being followed, poor-quality reports; and the time frames in which victim impact assessments are requested and submitted. This concurs with Burfurd (2012:116), who noted that magistrates would be more prone to accept reports that were concise, professional, well-structured and organised. The negative experiences that judicial officers are exposed to with poor-quality reports create a belief system that all reports compiled by social workers are to be approached with caution and this negatively influences the utilisation of VIRS. This places a greater challenge on victim services to ensure a more professional approach in delivering quality reports to change the mindset within the criminal justice system.

Changes required in South Africa and relating to the recommendations of this study include legislation governing victim services and specifically addressing the need for VIRS to be incorporated within the criminal justice system for all serious crimes (Western Cape Government, 2014:144). Directives need to be developed that address guidelines on victim needs assessment, victim referral procedures, trauma impact assessment and role clarification of social workers and interdisciplinary functioning. Judge Mocumie B.C. noted the need in South Africa for victim impact evidence during sentencing and the development of comprehensive guidelines, protocols and model instruments to facilitate a victim-centred approach (Mhlongo v The State (140/16) [2016] ZASCA 152, [2016];[24]). Guidelines must be practical and implementable. Screening for VIRs should not be dependent on the association or interpretation made by judicial officers of the impact of trauma. Guidelines should include practical issues such as screening of victims and trauma indicators; who will be responsible for these assessments; when would victim services become involved during the criminal investigation; what will be the protocol followed to do assessments of crime impact; what services will be available to victims; and how will victim services and the National Prosecuting Authority complement each other in terms of the service implementation. A stronger focus is required on victims' individual needs and harm suffered, and less standardisation of harm should be observed in the criminal justice system.

It is recommended that a victim-centred approach be advanced, and victim rights and victim services must be developed and strengthened to be on par with probation services in terms of capacity and its own unique specialisation. The focus of victim services should not only be on prevention, but also on providing services to the victim throughout the criminal justice process. This requires specialisation for victim services, the availability of social workers focusing on victim service, and an acknowledgement of the statutory obligation of social workers in victim services. Amendment of the Social Services Professional Act 110 of 1978 or the Probation Services Act 116 of 1991 is required to cover the classification of social workers providing victim services. Victim service providers should be properly 
screened, recruited and capacitated. Victim services should reflect the relevant experience, knowledge and professional conduct to form part of the criminal justice system. Social workers within victim services should meet the criteria established for expert services to enable a shift to promote the admissibility of behavioural evidence within the criminal justice system. Victim service providers who form part of the criminal justice system must be professional, reliable and credible to operate within criminal law. Social workers have a responsibility and a legal obligation therefore to reclaim their professionalism and status within the criminal justice system and to counter the current perceptions of unprofessional behaviour and poor report writing. Further research is required on the development of a standardised protocol to guide the assessment process of the impact of crime, the development of a screening tool for victim referrals, and screening requirements for the deployment of social workers to victim services with reference to the responsibilities of victim services within the criminal justice system.

Disclaimer: The findings and recommendations stemming from the investigation do not represent the views of the Business Unit concerned or the NPA or the Department of Justice and Constitutional Development, but only the professional experiences and interpretations of the participants.

\section{REFERENCES.}

BAILEY V THE STATE (454/11) [2012] ZASCA 154 [2012] 454.

BIFFI, E., MULDER, E., PEMBERTON, A., SANTOS, M., VALÉRIO, M., VANFRAECHEM, I. \& VAN DER VORM, B. 2016. IVOR Report: Implementing victim-oriented reform of the criminal justice system in the European Union.

BRADFORD, B. 2011. Voice, neutrality and respect: Use of victim support services, procedural fairness and confidence in the criminal justice system. Criminology and Criminal Justice, 11(4):345-366.

BURFURD, S. 2012. Specialist assessment practice in Victorian centres against sexual assault. CASA Forum: Victorian Centres Against Sexual Assault in conjunction with Royal Melbourne Institute of Technology: Victoria.

BURGESS, A.W. \& ROBERTS, A.R. 2010. Crime and victimology. In: Victimology theories and applications. Sudbury, Massachusetts: Jones and Bartlett Publishers, I.L.C: 1-30.

BUSCH-ARMENDARIZ, N., NSONWU, M.B. \& HEFFRON, L.C. 2014. A kaleidoscope: The role of the social work practitioner and the strength of social work theories and practice in meeting the complex needs of people trafficked and the professionals that work with them. International Social Work, 57(1):7-18.

BYRNE, M. \& HUGES, A. 2009. Victim impact report guidelines. Irish Psychologist, 36(1): 9 - 12.

CEASOR, D. 2017. Telephone interview. 03 July.

CHILD JUSTICE Act 75 of 2008. Government Gazette, vol.527, no.32225. Cape Town: Government Printers.

CRIMINAL PROCEDUR Act 51 of 1977. Government Gazette, vol.143. no 748. Cape Town: Government Printers.

DE KLERK, K.L. 2012. The role of the victim in the criminal justice system: A specific focus on victim offender mediation and victim impact statements. Pretoria: University of Pretoria. (M thesis)

DEPARTMENT SOCIAL DEVELOPMENT. 2009. National Policy Guidelines For Victim Empowerment. Chief Directorate Communication. Pretoria. [Online] Available: https://www.ohchr.org/Documents/Issues/Women/SR/Shelters/National\%20policy\%20guidelines\%20f or\%20victim\%20empowerment.pdf [Accessed 23/06/2019]. 
DEY, K., THORPE, J., TILLEY, A. \& WILLIAMS, J. 2011. The road to justice victim empowerment legislation in South Africa Road Map Report. [Online] Available: http://shukumisa.org.za/wpcontent/uploads/2017/09/The-Road-to-Justice-Research-Report.pdf [Accessed 27/10/2018].

DINISMAN, MOROZ, FARLEY, NAYLOR, PANAGIOTOU, FULLER, OWEN \& ALMEIDA. 2017. Understanding victims of crime. The impact of crime and support needs. Victim Support United Kingdom. [Online] Available: https://www.victimsupport.org.uk/sites/default/files/VS_Understanding victims of crime_web.pdf [Accessed 16/07/2019].

DOAK, J. 2015. Enriching trial justice for crime victims in common law systems: Lessons from transitional environments. International Review of Victimology, 21(2):139-160.

EAKRAMUDDIN. 2014. A critical study on the victims of rapes: An analysis. The role of judiciary and government in their rehabilitation and protection in India. Researcher, 6(6):5-59. University of Delhi, India. ISSN: 1553-9865. http://www.sciencepub.net/researcher

ELLISON, L. \& MUNRO, V.E. 2016. Taking trauma seriously: Critical reflections on the criminal justice process. The International Journal of Evidence \& Proof, 21(3): 1365-7127. [Online] Available: https://journals.sagepub.com/doi/10.1177/1365712716655168 [Accessed 18/03/2018].

FERGUSON, C. \& TURVEY, B.E. 2013. Victimology: A brief history with an introduction to forensic victimology. In: TURVEY, B. Forensic victimology: Examining violent crime victims in investigative and legal contexts. ( $2^{\text {nd }}$ ed).Elsevier Inc: $1-30$.

FISHER, C. \& SIMPSON, S. 2014. What matters: An analysis of victim satisfaction in a procedural criminal justice framework. University of Maryland, College Park. (PhD dissertation)

FULTON, S. 2015. Victim participation in criminal law proceedings: Survey of domestic practice for application to international crimes prosecutions. [Online] Available: https://redress.org/wpcontent/uploads/2017/11/Englishvictim-rights-report.pdf [Accessed 15/07/2019].

GREEFF, M. 2013. Information collection: Interviewing. In: J. READ, (ed). Research at grass roots for social and human science. $\left(4^{\text {th }}\right.$ ed). Hatfield, Pretoria: Van Schaik Publishers: $341-374$.

GREENBAUM, B. 2013. Compensation for victims of sexual violence in South Africa: A human rights approach to remedial criminal compensation provisions. Cape Town: University of Cape Town. (PhD)

HEATH, A., ARTZ, L., ODAYAN, M. \& GIHWALA, H. 2018. Improving case outcomes for sexual offences cases project: Pilot study on sexual offences courts. Cape Town, South Africa. Gender Health and Justice Research Unit. [online] Available: https://www.researchgate.net/publication/326606336,pdf [Accessed 27/10/2019].

HERMAN, J.L. 2005. Justice from the victim's perspective. Violence against Women, 11(5):571- 602. ISAACS V THE STATE (039/10) [2010] ZASCA 87 (31 May 2010).

JOUBERT, M. \& VAN WYK, C. 2014. Social work forensic reports in South African criminal courts: Inevitability in the quest for justice. Social Work/Maatskaplike Werk, 50(3):485-503.

LANDMAN, J. 2017. Personal interview. 16 May.

LANGTON, L. \& TRUMAN, J. 2014. Socio-emotional Impact of Violent Crime. U.S. Department of Justice, Office of Justice Programs. United States. [Online] Available: https://www.bjs.gov/content/pub/pdf/sivc.pdf [Accessed 18/04/2019].

LENS, K., PEMBERTON, A. \& BOGAERTS, S. 2013. Heterogeneity in victim participation: A new perspective on delivering a victim impact statement. European Journal of Criminology, 10(4):479495. 
MACHISA, M., JINA, R., LABUSCHAGNE, G., VETTEN, L., LOOTS, L., SWEMMER, S., MEYERSFELD, B. \& JEWKES, R. 2017. Rape justice in South Africa: Retrospective study of the investigation, prosecution and adjudication of reported rape cases from 2012. Pretoria, South Africa. MALATJI, H.Q. 2012. The social worker, as an expert witness in sexual offences committed against children. Potchefstroom: North-West University. (M thesis)

MANGEZI, M.S. 2014. An investigation into the specialized skills and knowledge required for forensic social work practice in South Africa. Cape Town: University of Cape Town. (M thesis)

MATYITYI V THE STATE (695/09) [2010] ZASCA 127; 2011 (1) SACR 40 (SCA); [2010] 2 All SA 424 (SCA) (30 September 2010).

MBOWANA, P.T. 2016. An assessment of governmental interventions in maintaining victim empowerment centres. University of Limpopo. (M thesis)

MHLONGO V THE STATE (140/16) [2016] ZASCA 152 [2016] ZASCA 152. (03 October 2016).

MOKELA V THE STATE (135/11) [2011] ZASCA 166; 2012 (1) SACR 431 (SCA) (29 September 2011).

MOFFETT, L. 2016. Victim impact reports in Northern Ireland: Victims' voices influencing sentencing? Criminal Law Review, (7):478-484.

MURPHY, K. \& BARKWORTH, J. 2014 Victim willingness to report crime to Police: Does procedural justice or outcome matter most? Victims \& Offenders, 9:2. Taylor Francis Online: 178204. doi: $10.1080 / 15564886.2013 .872744$

NATIONAL INSTITUTE OF MENTAL HEALTH. 2019. [Online] Available: https://www.nimh.nih.gov/health/topics/post-traumatic-stress-disorder-ptsd/index.shtml [Accessed 27/04/2020].

NEL, J.A. \& VAN WYK, H. 2013. Victim empowerment in South Africa. In: PEACOCK, R. Victimology in South Africa. (2 ${ }^{\text {nd }}$ ed). Pretoria: Van Schaik: 77-93.

NDOU V THE STATE (93/12) [2012] ZASCA 148 (28 September 2012).

O'CONNELL, F. 2012. Victim impact statements. Belfast, Northern Ireland Assembly. Research and Information Service Research Paper, NIAR952-11.

PHILLIPS, A. 2019. Experiences of judicial officers' inclusion of victim impact reports during the criminal justice process. Nelson Mandela Metro: Nelson Mandela University. (M thesis)

PREVENTION AND COMBATING OF TRAFFICKED PERSONS Act 7 of 2013.Government Gazette, vol.577, no. 36715. Cape Town: Government Printers.

PROBATION SERVICES Act 116 of 1991. Government Gazette, vol 313, no 1510. Cape Town: Government Printers.

PROBATION SERVICES AMENDMENT Act No 35 of 2002. Government Gazette, vol 449, no 24027. Cape Town: Government Printers.

RAHMAN, A. 2013. Victimology: Concept and history of victimology. University of Dhaka, Institute of Social Welfare and Research. SSRN Electronic Journal. doi: 10.2139/ssrn.2257668

RAUCH, J. 2001.The 1996 National rime Prevention Strategy. Centre for the study of ble: violence and reconciliation (CSVR). Institute for Security Studies. [Online] Availahttps://csvr.org.za/docs/crime/1996nationalcrime.pdf [Accessed 17/03/2018].

RAYEJIAN ASLI, M. 2014. Introducing general theory of victimology in criminal sciences. International Journal of Humanities, 20(3):53-79. 
ROBERTS, J.V. \& MANIKIS, M. 2011. Victim personal statements - A review of empirical research, Report for the Commissioner for Victims and Witnesses in England and Wales. University of Oxford. [Online] Available: https://www.justice.gov.uk/downloads/news/press-releases/victimscom/vps-research.pdf [Accessed 30/09/2017].

ROBERTS, J.V. 2009. Listening to the crime victim: Evaluating victim impact at sentencing and parole. Crime and Justice, 38(1):347-412. The University of Chicago Press. http://www.jstor.org/stable/10.1086/599203 [Accessed 01/10/2017].

ROME STATUTE OF THE INTERNATIONAL CRIMINAL COURT (last amended 2010), UN General Assembly, 17 July 1998, International Criminal Court ISBN No. 92-9227-227-6.

RONALDSON, D. \& MCCOY, S. 2016. Dissociation and the traumatic experience from a psychotherapeutic perspective. Dublin: Department of Counselling and Psychotherapy Dublin Business School, School of Arts. [Online] Available: https://esource.dbs.ie/bitstream/handle/10788/3145/hdip_ronaldson_d_2016.pdf?sequence=1 [Accessed 08/04/2018].

SAFERSPACES, 2019. What is the situation in South Africa? Safer spaces. [Online] Available: https://www.saferspaces.org.za/understand/entry/what-is-the-situation-in-south-africa [Accessed 13/04/2020].

SAPONARO, A. 2013. Theoretical approaches and perspectives in victimology. In: PEACOCK, R. (ed). Victimology in South Africa, $\left(2^{\text {nd }}\right.$ ed). Pretoria, South Africa: Van Schaik: 11-31.

STERN, P. 1997. Preparing and presenting expert testimony in child abuse litigation: A guide for expert witnesses and attorneys. London: Sage publishers.

SOCIAL SERVICES PROFESSIONAL Act 110 of 1978. Government Gazette, vol. 156, no. 1359. Cape Town: Government Printers.

SOUTH AFRICAN GOVERNMENT, 2019. Gender-based violence and femicide declaration. South African Government. [Online] Available: https://www.gov.za/GBVFdeclaration [Accessed 18/04/ 2020].

TERBLANCHE, S.S. 2013. The Child Justice Act: Procedural Sentencing Issues. Potchefstroom Electronic Law Journal/Potchefstroom se Elektroniese Regsblad, 16(1): 320-350.

TURVEY, B. E. \& CROWDER, S. (2017). Forensic investigations: An introduction. Elsevier Inc.: 1359 [Online]

Available:

https://books.google.co.za/books?id=A2GdBgAAQBAJ\&pg=PR8\&lpg=PR8\&dq=forensic+investigati ons+turvey+and +freeman\&source $=$ bl\&ots $=8$ oge 8 -

GwMc\&sig=ACfU3U1FIfI34aAkIgHH6iRS5MWnKu1YHA\&hl=en\&sa=X\&ved=2ahUKEwi-

69mH_4jpAhVXilwKHUGKDgMQ6AEwCHoECAwQAQ\#v=twopage\&q\&f=false [Accessed 16/07/ 2019].

TURVEY, B. \& PETHERICK, W. 2008. Forensic victimology. San Diego: Elsevier Science. Jones \& Bartlett Learning, LLC.

VAN CAMP, T. \& WEMMERS, J.A. 2013. Victim satisfaction with restorative justice: More than simply procedural justice. International Review of Victimology, 19(2): 117-143.

VAN DER HOVEN, AE. 2006. The criminologist as an expert witness in court. Acta Criminologica 19(2):155 - 161

VAN DER MERWE, A. 2013. A new role for crime victims? An evaluation of restorative justice procedures in the Child Justice Act 2008. De Jure, 4(46):1022. [Online] Available: http://www.saflii.org/za/journals/DEJURE/2013/43.pdf [Accessed 08 April 2018]. 
VICTIM SUPPORT EUROPE, 2013. Handbook for implementation of legislation and best practice for ictims ofcCrime in Europe. Brussels: Victim Support Europe. ISBN: 9782960123210. [Online] Available: http://victimsupporteurope.eu/activeapp/wpcontent/files_mf/1385974688NewVersionVSEHandbookforImplementation.pdf

[Accessed 20/05/2019].

VOSLOO, J.J. 2014. A sport management programme for educator training in accordance with the diverse needs of South African schools. Potchefstroom Campus of North-West University. 299-353. $(\mathrm{PhD}$ thesis). [Online]

Available: http://dspace.nwu.ac.za/bitstream/handle/10394/12269/Vosloo_JJ_Chapter_5.pdf; https://dspace.nwu.ac.za/bitstream/handle/10394/12269/Vosloo_JJ_Chapter_6.pdf [Accessed 01 /04/2018].

WASSERMAN, C. \& ELLIS, C.A. 2010. Impact of crime on victims. In: National Victim Assistance Academy, Tract 1, Foundation-Level Training:1-16. [Online] Available: https://ce4less.com/Tests/Materials/E075Materials.pdf [Accessed 01/10/ 2017].

WATLING, R. \& JAMES, V. 2012. Qualitative data analysis: Using NVivo. In: BRIGGS, A.R.J., COLEMAN M. \& MORRISON M. (eds). Research methods in educational leadership \& management (3d ed). London: SAGE:381-396.

WEDLOCK, E. \& TAPLEY, J. 2016. What works in supporting victims of crime: A rapid evidence assessment. Victims' Commissioner Report. (March):1-44. [Online] Available: https://researchportal.port.ac.uk/portal/en/publications/what-works-in-supporting-victims-ofcrime(d3ad0ff3-7f6d-4cc5-82201c250c5fe55e).html\%0Ahttp://victimscommissioner.org.uk/app/uploads/2014/10/What-works-insupporting-victims-of-crime.pdf [Accessed 04/11/2018].

WEMMERS, J. 2013. Victims' experiences in the criminal justice system and their recovery from crime. International Review of Victimology, 19(3):221-233. [Online] Available: http://journals.sagepub.com/doi/10.1177/0269758013492755 [ Accessed 18/03/2017].

WESTERN CAPE GOVERNMENT: Social Development, 2014. An evaluation of the victim empowerment programme. Gender ealth and Justice Research Unit. Faculty of Health Science University of Cape Town. Cape Town.

WHITE, R. 2014. Testifying in court as a victim of crime: Vocabulary required by illiterate individuals with little or no functional speech. Pretoria: University of Pretoria. (M thesis)

WHITE, R.M., BORNMAN, J. \& JOHNSON, E. 2015. Testifying in court as a victim of crime for persons with little or no functional speech: Vocabulary implications. Centre for Augmentative and Alternative Communication, University of Pretoria. Child Abuse Research: South African Journal, 16(1):1-14. 